\title{
Quality characteristics and antioxidant activities of aged black Liriope platyphylla
}

\author{
Da Hee Kim, Da Rae Oh, Seung Yeon Baek, Mee Ree Kim* \\ Department of Food \& Nutrition, Chungnam National University, Daejeon 34134, Korea
}

\section{숙성 흑 맥문동의 품질특성 및 항산화능}

\author{
김다희 · 오다래 · 백승연 · 김미리* \\ 충남대학교 식품영양학과
}

\begin{abstract}
The purpose of this study was to examine the physicochemical properties and antioxidant activities of aged black Liriope platyphylla (ALP) and raw Liriope platyphylla (RLP). RLP was aged for 14 days at high humidity $(90 \%$ and $95 \%$ ) and temperatures $\left(50^{\circ} \mathrm{C}\right.$ and $\left.80^{\circ} \mathrm{C}\right)$. With the passage of the storage period, the moisture content significantly decreased to $64.26 \%$. During storage, the sugar content increased to $16.00{ }^{\circ}$ Brix, while the reducing sugar content increased to $2.62 \%$. With increasing storage time, the $\mathrm{pH}$ decreased to 3.63 , while the acidity increased to $0.032 \%$. In the Hunter color system, L (lightness) and b (yellowness) values of ALP were lower than those of RLP, while the redness value of ALP was higher than that of RLP. During storage, the browning index value significantly increased to 77.08. The increase in total phenol content of ALP after 14 days of aging was more than that of RLP. IC 50 $_{50}$ values for both 1,1-diphenyl-2-picrylhydrazyl (DPPH) and hydroxyl radical scavenging activities of ALP after 14 days of aging were lower than those of RLP. Based on these results, it is suggested that aged black Liriope platyphyllas can a useful food material, in terms of both physicochemical properties and antioxidant activities.
\end{abstract}

Key words : Liriope platyphylla, aged black Liriope platyphylla, quality characteristics, antioxidant activities

\section{서 론}

맥문동(Liriope platyphylla Wang et Tang)은 백합과의 다 년생 초본식물로 뿌리 끝에 형성된 짧은 방추형 덩이뿌리를 이용하며, 한국, 일본, 중국을 비롯한 동북아시아 지역에서 주로 한약재로 이용하여왔으며, 개맥문동(Liriope spicata L.) 및 Ophiopogon 속 소엽맥문동(Ophiopogon japonicus Ker-Gawler)으로 구별된다(1,2).

최근 건강에 대한 소비자들의 관심 증대와 서구화된 식 생활로 인해 사회적 문제로 대두된 각종 성인병을 예방하고 자 건강증진과 질병 예방 및 개선에 도움이 되는 생리활성

*Corresponding author. E-mail : mrkim@cnu.ac.kr Phone : 82-42-821-6837, Fax : 82-42-821-8887

Received 27 May 2019; Revised 21 July 2019; Accepted 24 July 2019.

Copyright (c) The Korean Society of Food Preservation. All rights reserved.
성분 함유 식품에 대한 관심과 개발이 증가하고 있다(3-5). 맥문동의 주요 생리활성 성분으로는 spicatoside와 ophiopogonin와 같은 스테로이드계 사포닌이 주성분으로 그 이외에도, $\beta$-sitosterol, stigmasterol 및 campesterol과 같은 sterol, ophiopogonanone과 ophiopogonone 등의 homoisoflavonoid류, oligosaccharide 등이 있다(3,6-8).

맥문동은 혈당강하, 항염증, 항당뇨 및 항암효과 등이 있는 것으로 알려져 있으며, 한방에서는 맥문동 열수 추출 물을 혈당강하, 당뇨 예방 및 항염증제로 사용하여 왔고, 더불어 양음윤폐, 익위생진, 청신제번 및 거담, 진해, 자양, 강장, 이뇨, 지갈 등에도 맥문동 열수 추출물을 이용하고 있다(9). 허준의 <동의보감(10)>에서는 “성질이 약간 차고 맛이 달며 독이 없다. 허로(虛勞)로 인한 객열(客熱)로 입이 마르고 갈증이 있는 것을 주치(主治)하며, 폐위(肺瘘)로 인 한 토농(叶膿)을 다스리고, 열독(熱毒)으로 인해 몸이 검고 눈이 노래지는 것을 치료하며, 심장을 보익하고 폐장을 서 늘하게 하여 정신을 보전하고 맥기(脈氣)를 안정되게 한 
다.”라고 하였다. 맥문동은 과잉섭취 시에 의한 독성이 없지 만 한방에서는 온경탕, 감초탕, 청심연자식, 맥미지황탕, 증액탕, 생맥산 등에 활용되고 있다(11).

맥문동의 생리활성에 관한 연구로는 맥문동 물 추출물의 당뇨예방(12), 맥문동의 prosapogenin III에 의한 항염증 효 과(13), 맥문동의 spicatoside $\mathrm{A}, \mathrm{B}$ 의 구조를 가진 스테로이 드계 사포닌추출물에 의한 항암활성(14)등이 보고되었다. 또한 최근 환경보건 분야에서 심각한 문제가 되는 미세먼지 (15)에도 맥문동이 효과가 있음이 보고되었다. 즉, 맥문동 이 미세먼지에 의한 폐탐식세포나 상피세포의 증가된 염증 cytokine인 IL-6, IL-16 등을 용량 의존적으로 억제하여(16), 미세먼지 및 호흡기 질환인 천식 치료 및 방어기전에 작용 한다고 하였다 $(17,18)$.

한방에서와는 달리 식품공전에는 맥문동을 식품제조·가 공에서 부원료로서 사용할 수 있는 식물 중 하나로 분류하 고 있다(19). 맥문동을 식품에 제한적으로 사용하도록 한 것은 아마도 본초강목에 언급된 맥문동의 심지 때문으로, 심이 제거되지 않으면 가슴이 답답해질 수 있다고 기록한데 기인된 것으로 한의학에서는 거심한 맥문동을 사용한다. 따라서 맥문동은 전처리가 필요한데, 예로부터 알려진 전 처리 방법으로는 따뜻한 물에 씻거나 끓는 물에 불려서 심을 제거하거나, 술에 담갔다가 찹쌀에 버무려 찌는 법, 생강즙에 볶는 법, 쌀과 함께 살짝 볶는 법 등이 알려져 있으며, 맥문동의 전처리 방법 중 증숙 또는 주증 전처리 후 건조 혹은 볶았을 경우, 주증건조 볶은 맥문동의 항산화 능이 가장 좋았다고 보고하였다(20).

예로부터 성질이 차가워 설사 등의 부작용이 우려되는 지황의 경우 막걸리에 침지 후 구증구포하여 숙지황으로 만들어 복용하였다. 맥문동을 이용하여 식품이나 음료로 개발된 연구로는 맥문동 설기떡(21), 맥문동 국수(22), 맥문 동 양갱(23), 맥문동 음료(24), 구기자-맥문동 전통주(25), 구기자-맥문동 막걸리(26) 등이 있다.

따라서 본 연구에서는 맥문동을 막걸리에 침지 후 숙성시 킨 흑 맥문동의 이화학적 특성과 항산화성을 분석하여 맥문 동의 폭넓은 활용을 위한 기초자료로 활용하고자 하였다.

\section{재료 및 방법}

\section{실험재료}

본 실험에 사용된 맥문동은 금산군 농업기술센터 특화작 목에서 재배한 것을 사용하였고, 막걸리는 포천 쌀 막걸리 (Idong Baegun Casting, Pocheon, Korea)를 사용하였다.

\section{시료의 제조}

숙성 흑 맥문동은 맥문동을 선별하고 깨끗이 세정하여 막걸리에 주침한 후 본 연구실에서 개발하여 특허 등록한
제조방법(출원번호; 1020170022929)에 따라 막걸리 350 $\mathrm{mL}$ 에 맥문동 $350 \mathrm{~g}$ 을 고르게 섞고 실온에서 24시간 동안 침지시킨 후 온도 $50^{\circ} \mathrm{C}, 80^{\circ} \mathrm{C}$, 습도 $90 \%, 95 \%$ 조건의 항온항 습기에서 14 일 동안 숙성시켜 제조하였다.

\section{수분 함량}

시료의 수분함량은 $\mathrm{AOAC}$ 방법에 따라 $105^{\circ} \mathrm{C}$ 상압가열 건조법으로 측정하였다(28).

\section{가용성 고형물 함량 및 환원당}

가용성 고형물 함량은 시료 $2 \mathrm{~g}$ 에 증류수 $8 \mathrm{~mL}$ 을 $\mathrm{Bag}$ Mixer(Model 400, Interscience, Mourjou, France)로 균질화 (속도 7, 2분)하였다. 원심분리기(Combi-514R, Hanil, Hwaseong, Korea) $3,000 \mathrm{rpm}, 4^{\circ} \mathrm{C}$ 에서 15 분간 원심분리하여 얻은 상징액을 취하여 당도계(N-1E Brix 0-92\%, Atago, Tokyo, Japan)를 사용하여 측정하였다. 환원당은 시료 2 $\mathrm{g}$ 에 증류수 $8 \mathrm{~mL}$ 을 Bag Mixer(Model 400, Interscience, Mourjou, France)로 균질화(속도 7, 2분)한 것을 원심분리기 (Combi-514R, Hanil, Hwaseong, Korea) 3,000 rpm, $4^{\circ} \mathrm{C}$ 에서 15 분간 원심분리하여 얻은 상징액을 취하여 dinitrosalicylic $\operatorname{acid(DNS)ㅇㅔ~ㅇㅢㅎㅏㄴ~ㅂㅣㅅㅐㄱㅂㅓㅂㅇㅡㄹㅗ~ㅂㅜㄴㄱㅘㅇㄱㅘㅇㄷㅗㄱㅖ(Model~UV-1800~}$ $240 \mathrm{~V}$, Beckman, Fullerton, CA, USA)를 사용하여 $550 \mathrm{~nm}$ 에 서 흡광도를 측정하였다. 표준곡선은 Glucose(Duksan Pharmaceutical Co., Ltd., Asan, Korea)를 농도별로 반응시 켜 작성하였다.

\section{$\mathrm{pH}$ 및 산도}

$\mathrm{pH}$ 는 $\mathrm{AOAC}$ 방법(28)에 따라 시료 $2 \mathrm{~g}$ 에 증류수 $8 \mathrm{~mL}$ 을 Bag Mixer(Model 400, Interscience, Mourjou, France)로 균 질화(속도 7, 2분)하였다. 원심분리기(Combi-514R, Hanil, Hwaseong, Korea) $3,000 \mathrm{rpm}, 4^{\circ} \mathrm{C}$ 에서 15 분간 원심분리하여 얻은 상징액을 취하여 $\mathrm{pH}$ meter(420 Benchtop, Orion Research, Washington, DC, USA)로 측정하였다.

산도는 $\mathrm{AOAC}$ 방법(28)에 따라 $\mathrm{pH}$ 측정 시료와 동일한 상징액 $10 \mathrm{~mL}$ 을 취하여 $0.1 \mathrm{~N} \mathrm{NaOH}$ (Samchun, Pyeongtaek, Korea)를 첨가하였을 때 $\mathrm{pH} 8.3$ 까지 도달하는데 필요한 $\mathrm{NaOH}$ 양 $(\mathrm{mL})$ 을 acetic acid 함량(\%)으로 환산하여 총산 함량을 표시하였다.

\section{색도 및 갈변도}

색도는 시료를 막자사발에서 으깨어 페트리디쉬 $(50 \times 12$ $\mathrm{mm}$ )에 담아 색도를 측정하였다. 색차계(Model ND-1001 DP, Nippon Denshoku Co., Ltd., Tokyo, Japan)를 사용하여 Hunter L값(명도, lightness), $\mathrm{a}$ 값(적색도, redness), $\mathrm{b}$ 값(황색 도, yellowness) 및 $\triangle \mathrm{E}$ 값(색차지수)을 측정하여 평균값으 로 나타내었다. Standard color value는 L값 108.85, a값 -0.12, $\mathrm{b}$ 값 -4.44, $\triangle \mathrm{E}$ 값 0.00 인 calibration plate를 표준으로 사용하 
였다. 갈변도(Browning Index)는 다음의 식을 이용하여 계 산하였다.

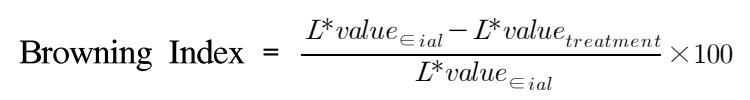

\section{총 페놀 함량}

총 페놀 함량 측정은 시료의 페놀성 화합물과 phosphomolybdic acid가 반응해 청색으로 환원되는 Folin-Denis법으로 측정하였다(29). 시료 $1.5 \mathrm{~g}$ 에 methanol $50 \mathrm{~mL}$ 을 넣은 후 15 시간 동안 잘 교반하여 원심분리기 (Combi-514R, Hanil, Hwaseong, Korea) 3,000 rpm, $4{ }^{\circ} \mathrm{C}$ 에서 10 분간 원심분리하여 얻은 상징액을 evaporator(Whatman, Buckinghamshire, UK)로 용매를 휘발하여 추출물만 얻었 다. 추출물 $95 \mathrm{mg}$ 당 PBS Buffer $1 \mathrm{~mL}$ 을 첨가하여 $95 \mathrm{mg} / \mathrm{mL}$ 농도의 추출물 용액을 시료 용액으로 사용하였다. 시료 추 출액에 Folin-Denis reagent과 $7.5 \% \mathrm{Na}_{2} \mathrm{CO}_{3}$ 용액을 넣고 암실에서 30분간 반응시킨 후 분광광도계(Model UV-1800 $240 \mathrm{~V}$, Beckman, Fullerton, CA, USA)를 이용하여 $760 \mathrm{~nm}$ 에 서 흡광도를 측정하였고, standard는 tannic acid(Yakuri Pure Chemicals Co., Ltd., Kyoto, Japan)를 사용하였다.

\section{DPPH(1,1-diphenyl-2-picryl hydrazyl) radical 소거능}

시료 $1.5 \mathrm{~g}$ 에 methanol $50 \mathrm{~mL}$ 을 넣은 후 15 시간 동안 잘 교반한 것을 원심분리기(Combi-514R, Hanil, Hwaseong, Korea) $3,000 \mathrm{rpm}, 4^{\circ} \mathrm{C}$ 에서 10 분간 원심분리하여 얻은 상징 액을 evaporator(Whatman, Buckinghamshire, UK)로 용매를 휘발하여 추출물만 얻었다. 추출물 $100 \mathrm{mg}$ 당 $1 \mathrm{~mL}$ methanol을 첨가하여 $100 \mathrm{mg} / \mathrm{mL}$ 농도의 추출물 용액을 제조하여 시료 용액으로 사용하였다. 시료용액 $50 \mu \mathrm{L}$ 에 $1.5 \times 10^{-4} \mathrm{mM}$ DPPH(1,1-diphenyl-2-picrylhydrazyl)용액 150 $\mu \mathrm{L}$ 을 가한 후 30 분 후에 분광광도계(Model UV-1800 240 $\mathrm{V}$, Beckman, Fullerton, CA, USA)를 이용하여 $515 \mathrm{~nm}$ 에서 흡광도를 측정하였으며 radical 소거능(\%)을 다음의 식으로 계산한 후 각 농도별 radical 소거능에 대한 검량선에서 radical 소거능이 $50 \%$ 가 되는 농도인 $\mathrm{IC}_{50}$ 을 구하였다.

Free radical scavenging activity $(\%)=\frac{\mathrm{Abs}_{\mathrm{DPPH}}-\mathrm{Abs}_{\text {sample }}}{\mathrm{Abs}_{\mathrm{DPPH}}} \times 100$

\section{Hydroxyl radical 소거능}

시료 $1.5 \mathrm{~g}$ 에 methanol $50 \mathrm{~mL}$ 을 넣은 후 15 시간 동안 잘 교반한 후 원심분리기(Combi-514R, Hanil, Hwaseong, Korea) $3,000 \mathrm{rpm}, 4^{\circ} \mathrm{C}$ 에서 10 분간 원심 분리하여 얻어진 상징액을 evaporator(Whatman, Buckinghamshire, UK)로 용 매를 휘발하여 추출물만 얻었다. 추출물 $45 \mathrm{mg}$ 당 $\mathrm{PBS}$
Buffer $1 \mathrm{~mL}$ 을 첨가하여 $45 \mathrm{mg} / \mathrm{mL}$ 농도의 추출물 용액을 제조하여 시료 용액으로 사용하였다. 추출된 시료 용액 $0.15 \mathrm{~mL}$ 에 buffer $0.35 \mathrm{~mL}, 3 \mathrm{mM}$ deoxyribose, $0.1 \mathrm{mM}$ ascorbic acid, $0.1 \mathrm{mM}$ EDTA, $0.1 \mathrm{mM} \mathrm{FeCl}_{3}, 1 \mathrm{mM} \mathrm{H} \mathrm{H}_{2}$ 용액 $0.1 \mathrm{~mL}$ 을 넣어 잘 교반한 후 $37^{\circ} \mathrm{C}$ 에서 1 시간 동안 반응시켰다. 반응이 끝난 후 $2 \% \mathrm{TCA}$ 용액과 $1 \% \mathrm{TBA}$ 용액 을 잘 섞은 후 $100^{\circ} \mathrm{C}$ 에서 20 분간 반응한 후 실온으로 냉각하 여 원심분리기(Combi-514R, Hanil, Hwaseong, Korea)로 원 심분리한 뒤 취한 상징액을 분광광도계(Model UV-1,800 $240 \mathrm{~V}$, Beckman, Fullerton, CA, USA)를 이용하여 $532 \mathrm{~nm}$ 에 서 흡광도를 측정하였다. radical 소거능 $(\%)$ 을 다음의 식으 로 계산한 후 각 농도별 radical 소거능에 대한 검량선에서 radical 소거능이 $50 \%$ 가 되는 농도인 $\mathrm{IC}_{50}$ 을 구하였다.

Free radical scavenging effect $(\%)=\frac{\mathrm{Abs}_{\text {blank }}-\mathrm{Abs}_{\text {sample }}}{\mathrm{Abs_{ \text {blank } }}} \times 100$

\section{통계처리}

실험 결과는 모든 실험을 3번 반복 측정한 값을 SPSS 24.0(Statistical Package for Social Sciences, SPSS Inc., Chicago, IL, USA) software package 프로그램 중에서 기술 통계를 실시하여 ‘평균 \pm 표준편차’로 나타내었고, 분산분석 (ANOVA Test)을 실시하여 유의성이 있는 경우에 Duncan 의 다중범위 검정(Duncan's multiple range test)으로 시료의 날짜별 유의차를 검증하였다 $(\mathrm{p}<0.05)$.

\section{결과 및 고찰}

\section{수분함량}

숙성기간에 따른 숙성 흑 맥문동의 수분함량 측정 결과 는 Table 1과 같다. 막걸리에 침지한 직후 숙성 전 맥문동 즉 대조군의 수분함량은 $89.22 \%$, 숙성 3 일차 맥문동은 $84.28 \%$, 숙성 5 일차에 맥문동은 $76.36 \%$, 숙성 8 일차 맥문동 은 $74.70 \%$, 숙성 11 일차 맥문동은 68.20 , 숙성 14 일차 맥문

Table 1. Moisture content of Liriope platyphylla during storage

\begin{tabular}{cc}
\hline Storage days & Moisture content $(\%)$ \\
\hline $0\left(\right.$ Control $\left.^{1)}\right)$ & $89.22 \pm 1.56^{\mathrm{a} 2)}$ \\
3 & $84.28 \pm 4.55^{\mathrm{a}}$ \\
5 & $76.36 \pm 4.54^{\mathrm{b}}$ \\
8 & $74.70 \pm 2.51^{\mathrm{b}}$ \\
11 & $68.20 \pm 2.81^{\mathrm{c}}$ \\
14 & $64.26 \pm 0.94^{\mathrm{c}}$ \\
\hline
\end{tabular}

${ }^{1)}$ Control: Liriope platyphylla.

${ }^{2)}$ Means \pm SD ( $n=3$ ) within each column followed by the same letter are significantly different $(p<0.05)$. 
동은 $64.26 \%$ 로 숙성이 진행됨에 따라 수분함량이 유의적으 로 감소하였다(p<0.05). 이는 흑마늘의 이화학적 특성(30) 에서 생마늘을 흑마늘로 제조하고, 흑삼 제조과정(31)에서 인삼을 흑삼으로 제조할 때 수분함량이 감소하는 결과와 유사하였다. 수분함량은 고온의 항온항습 조건에서 숙성기 간이 지남에 따라 수분이 증발되어 점차 감소하는 것으로 생각된다(32).

\section{가용성 고형물 함량 및 환원당 측정}

숙성기간에 따른 숙성 흑 맥문동의 가용성 고형물 함량 및 환원당 측정 결과는 Table 2 와 같다. 대조군인 막걸리에 침지한 직후 숙성 전 대조군 맥문동의 가용성 고형물 함량 은 $7.00{ }^{\circ} \mathrm{Brix}$, 숙성 3 일차에는 $8.00{ }^{\circ} \mathrm{Brix}$, 숙성 5 일차에는 $10.00{ }^{\circ} \mathrm{Brix}$, 숙성 8 일차에는 $11.17^{\circ} \mathrm{Brix}$, 숙성 11 일차에는 $15.00{ }^{\circ} \mathrm{Brix}$, 숙성 14 일차에는 $16.00{ }^{\circ} \mathrm{Brix}$ 로 숙성이 진행됨 에 따라 증가하는 경향을 보였다. 대조군과 숙성 맥문동 간에는 모두 유의적인 차이를 나타냈다( $<<0.05)$. 환원당은 대조군 맥문동이 $0.06 \%$, 숙성 3 일차는 $0.37 \%$, 숙성 5 일차는 $0.59 \%$, 숙성 8 일차는 $0.92 \%$, 숙성 11 일차는 $2.04 \%$, 숙성 14 일차는 $2.62 \%$ 로 숙성기간이 경과함에 따라 유의적으로 증가하였다(p<0.05). 한편, 맥문동의 유리당 함량을 분석한 결과(3)에 의하면, 생맥문동에서 올리고당은 약 $23.22 \%$ 를 함유하고 있었고, 그 다음으로 많은 당은 sucrose로 $1.42 \%$ 이 었으며, glucose와 fructose는 각각 $0.66 \%$ 및 $0.81 \%$ 를 함유 하고 있었으며, 열풍 건조 맥문동에서는 올리고당이 $57.57 \%$ 로 높았고, 단당류에서는 fructose의 함량이 $5.06 \%$ 로 증가하였다고 보고하여 가열처리 공정에서 환원당이 증가함을 보여준 결과에서와 같이 본 실험에서도 맥문동 중의 다당류가 막걸리로 전처리하는 동안 그리고 열처리에 의해 숙성하는 동안에 올리고당이 당류로 가수분해되어 가용성 고형물 함량 및 환원당이 높게 나타난 것으로 생각 된다 $(3,4,32)$. 숙성기간이 경과함에 따라 가용성 고형물 함 량이 증가하고 환원당 함량이 증가한 결과는 숙성 흑율피 (4)에서 숙성기간에 따라 흑율피의 가용성 고형물 함량 및 환원당 함량이 증가하는 것과 같은 경향을 보였다.

Table 2. Sugar and reducing sugar content of Liriope platyphylla during storage

\begin{tabular}{ccc}
\hline Storage days & Sugar content $\left({ }^{\circ}\right.$ Brix $)$ & Reducing sugar content (\%) \\
\hline $0\left(\right.$ Control $\left.^{1)}\right)$ & $7.00 \pm 0.00^{\mathrm{f} 2}$ & $0.06 \pm 0.00^{\mathrm{f}}$ \\
3 & $8.00 \pm 0.00^{\mathrm{e}}$ & $0.37 \pm 0.00^{\mathrm{e}}$ \\
5 & $10.00 \pm 0.00^{\mathrm{d}}$ & $0.59 \pm 0.00^{\mathrm{d}}$ \\
8 & $11.17 \pm 0.29^{\mathrm{c}}$ & $0.92 \pm 0.00^{\mathrm{c}}$ \\
11 & $15.00 \pm 0.00^{\mathrm{b}}$ & $2.04 \pm 0.00^{\mathrm{b}}$ \\
14 & $16.00 \pm 0.00^{\mathrm{a}}$ & $2.62 \pm 0.00^{\mathrm{a}}$ \\
\hline
\end{tabular}

\footnotetext{
${ }^{1)}$ Control: Liriope platyphylla.

${ }^{2)}$ Means $\pm S D$ ( $n=3$ ) within each column followed by the same letter are significantly different $(p<0.05)$
}

\section{$\mathrm{pH}$ 및 산도}

숙성기간에 따른 숙성 흑 맥문동의 $\mathrm{pH}$ 및 산도 측정 결과 는 Table 3과 같다. 숙성 맥문동의 $\mathrm{pH}$ 는 숙성이 진행됨에 따라 점차 감소하는 경향을 나타냈는데, 대조군 맥문동의 $\mathrm{pH}$ 는 4.50 , 숙성 3 일차는 4.39 , 숙성 5 일차는 4.38 , 숙성 8 일차는 4.28 , 숙성 11 일차는 3.94 , 숙성 14 일차는 3.63 으로 모든 시료 간의 유의적인 차이를 나타냈다 $(\mathrm{p}<0.05)$. 대조군 맥문동의 산도는 $0.004 \%$, 숙성 3 일차에 $0.005 \%$, 숙성 5 일차 에 $0.009 \%$, 숙성 8 일차에 $0.015 \%$, 숙성 11 일차에 $0.021 \%$, 숙성 14 일차에 $0.032 \%$ 로 숙성 기간에 따라 점차 증가하며, 모든 시료 간의 유의적인 차이를 나타냈다 $(\mathrm{p}<0.05)$. 숙성기 간이 진행될수록 $\mathrm{pH}$ 는 낮아지고 산도는 증가하며, $\mathrm{pH}$ 와 산도가 상응되는 결과임을 보여주었다. 이와 같은 결과는 숙성 흑율피(4)에서 숙성이 진행될수록 $\mathrm{pH}$ 가 감소하고 산 도는 증가하는 보고, 지황 및 숙지황(34)에서 발효로 인해 $\mathrm{pH}$ 가 낮아지고, 산도가 증가하는 보고와 일치하였다. 이는 숙성이 진행될수록 막걸리의 효모 등의 작용으로 유기산의 생성이 증가됨에 따라 숙성 맥문동의 $\mathrm{pH}$ 는 낮아지고, 이로 인해 산도가 증가하는 것으로 생각된다(35).

Table 3. $\mathrm{pH}$ and acidity of Liriope platyphylla during storage

\begin{tabular}{ccc}
\hline Storage days & $\mathrm{pH}$ & Acidity (\%) \\
\hline $0\left(\right.$ Control $\left.^{1)}\right)$ & $4.50 \pm 0.00^{\mathrm{a} 2)}$ & $0.004 \pm 0.005^{\mathrm{f}}$ \\
3 & $4.39 \pm 0.01^{\mathrm{b}}$ & $0.005 \pm 0.005^{\mathrm{e}}$ \\
5 & $4.38 \pm 0.00^{\mathrm{c}}$ & $0.009 \pm 0.009^{\mathrm{d}}$ \\
8 & $4.28 \pm 0.00^{\mathrm{d}}$ & $0.015 \pm 0.015^{\mathrm{c}}$ \\
11 & $3.94 \pm 0.01^{\mathrm{e}}$ & $0.021 \pm 0.021^{\mathrm{b}}$ \\
14 & $3.63 \pm 0.00^{\mathrm{f}}$ & $0.032 \pm 0.032^{\mathrm{a}}$ \\
\hline
\end{tabular}

${ }^{1)}$ Control: Liriope platyphylla.

${ }^{2)}$ Means \pm SD ( $n=3$ ) within each column followed by the same letter are significantly different $(\mathrm{p}<0.05)$.

\section{색도 및 갈변도}

숙성기간에 따른 숙성 흑 맥문동의 색도인 L값(명도, lightness), $\mathrm{a}$ 값(적색도, redness), $\mathrm{b}$ 값(황색도, yellowness) 및 $\triangle \mathrm{E}$ 값(색차지수)를 측정한 결과는 Table 4와 같다. 숙성 맥문동의 $\mathrm{L}$ 값은 숙성이 진행됨에 따라 점차 감소하는 경향 을 나타냈는데, 대조군 맥문동의 $\mathrm{L}$ 값은 44.23 , 숙성 3 일차는 37.92 , 숙성 5 일차는 36.47 , 숙성 8 일차는 28.99 , 숙성 11 일차 는 15.45 , 숙성 14 일차는 10.14 로 모든 시료 간의 유의적인 차이를 나타냈다 $(\mathrm{p}<0.05)$. $\mathrm{a}$ 값은 숙성이 진행됨에 따라 점 차 증가하는 경향을 나타냈는데, 대조군 맥문동 0.82 , 숙성 3 일차 2.82 , 숙성 5 일차 5.01 , 숙성 8 일차 5.52 , 숙성 11 일차 6.57 , 숙성 14 일차 7.06 으로 모든 시료 간의 유의적인 차이 를 나타냈다 $(\mathrm{p}<0.05) . \mathrm{b}$ 값은 대조군 맥문동 13.70 , 숙성 3 일 차 13.58 , 숙성 5 일차 13.03 , 숙성 8 일차 10.75 , 숙성 11 일차 5.44 , 숙성 14 일차 2.76 으로 숙성이 진행됨에 따라 값이 
감소하며, 숙성 흑맥문동 간의 유의적인 차이를 나타냈다 $(\mathrm{p}<0.05) . \triangle \mathrm{E}$ 값은 대조군 맥문동 67.32 , 숙성 3 일차 73.62 , 숙성 5 일차 74.85 , 숙성 8 일차 81.78 , 숙성 11 일차 94.20 , 숙성 14 일차 99.10 로 유의적으로 증가하였다 $(\mathrm{p}<0.05)$. 이러 한 결과는 숙성 흑율피(4)에서 숙성기간에 따라 $\mathrm{L}$ 값과 $\mathrm{b}$ 값 은 감소하고, $\mathrm{a}$ 값은 증가하는 경향과 유사하다. 이는 맥문동 자체의 비효소적 갈변반응인 마이얄 반응에 의해 갈변도가 증가하여 색이 어두워짐에 따른 것으로 생각된다(29).

Table 4. Hunter's color values of Liriope platyphylla during storage

\begin{tabular}{ccccc}
\hline Storage days & $\mathrm{L}$ & $\mathrm{a}$ & $\mathrm{b}$ & $\triangle \mathrm{E}$ \\
\hline $0\left(\right.$ Control $\left.^{1}\right)$ & $44.23 \pm 0.27^{\mathrm{a} 2)}$ & $0.82 \pm 0.38^{\mathrm{a}}$ & $13.70 \pm 0.02^{\mathrm{a}}$ & $67.32 \pm 0.22^{\mathrm{a}}$ \\
3 & $37.92 \pm 0.10^{\mathrm{b}}$ & $2.82 \pm 0.03^{\mathrm{b}}$ & $13.58 \pm 0.15^{\mathrm{a}}$ & $73.62 \pm 0.10^{\mathrm{b}}$ \\
5 & $36.47 \pm 0.08^{\mathrm{c}}$ & $5.01 \pm 0.06^{\mathrm{c}}$ & $13.03 \pm 0.04^{\mathrm{b}}$ & $74.85 \pm 0.07^{\mathrm{c}}$ \\
8 & $28.99 \pm 0.24^{\mathrm{d}}$ & $5.52 \pm 0.08^{\mathrm{d}}$ & $10.75 \pm 0.09^{\mathrm{c}}$ & $81.78 \pm 0.23^{\mathrm{d}}$ \\
11 & $15.45 \pm 0.08^{\mathrm{e}}$ & $6.57 \pm 0.08^{\mathrm{e}}$ & $5.44 \pm 0.04^{\mathrm{d}}$ & $94.20 \pm 0.07^{\mathrm{e}}$ \\
14 & $10.14 \pm 0.09^{\mathrm{f}}$ & $7.06 \pm 0.14^{\mathrm{f}}$ & $2.76 \pm 0.01^{\mathrm{e}}$ & $99.10 \pm 0.08^{\mathrm{f}}$ \\
\hline
\end{tabular}

${ }^{1)}$ Control: Liriope platyphylla.

${ }^{2}$ Means \pm SD ( $n=3$ ) within each column followed by the same letter are not significantly different $(\mathrm{p}<0.05)$

숙성 흑 맥문동의 갈변도 측정 결과는 Table 5 와 같다. 갈변도는 숙성 3 일차에 14.27 , 숙성 5 일차에 17.55 , 숙성 8 일차에 34.45 , 숙성 11 일차에 65.07 , 숙성 14 일차에 77.08 로 대조군 맥문동을 숙성할수록 갈변반응이 증가해 색이 진한갈색으로 변하게 된다. 맥문동에 함유된 다당류가 숙 성으로 인해 환원당으로 되고 고온의 열에 의해 비효소적 갈변 반응이 진행되어 갈색의 멜라노이딘 색소가 증가하였 기 때문으로(29), 이는 숙성 중 환원당의 증가(Table 2)가 뒷받침해준다.

Table 5. Browning Index of Liriope platyphylla during storage

\begin{tabular}{cc}
\hline Storage days & Browning Index \\
\hline $0\left(\right.$ Control $\left.^{1)}\right)$ & - \\
3 & $14.27 \pm 0.22^{22)}$ \\
5 & $17.55 \pm 0.18^{\mathrm{d}}$ \\
8 & $34.45 \pm 0.55^{\mathrm{c}}$ \\
11 & $65.07 \pm 0.17^{\mathrm{b}}$ \\
14 & $77.08 \pm 0.19^{\mathrm{a}}$ \\
\hline
\end{tabular}

\footnotetext{
${ }^{1)}$ Control: Liriope platyphylla.

${ }^{2)}$ Means $\pm \mathrm{SD}(\mathrm{n}=3)$ within each column followed by the same letter are significantly different $(p<0.05)$
}

\section{총 페놀 함량}

대조군 맥문동과 숙성 흑 맥문동의 총 페놀 함량 측정 결과는 Fig. 1 과 같다. Tannic acid를 표준용액으로 하여
작성한 검정곡선으로부터 분석한 총 페놀 함량은 대조군 맥문동이 $2.116 \mathrm{mg} / \mathrm{mL}$, 숙성 14 일차 흑 맥문동이 15.752 $\mathrm{mg} / \mathrm{mL}$ 로 숙성 흑 맥문동의 총 페놀 함량이 대조군 맥문동 에 비해 약 7.5 배 높은 것으로 나타났다. 이러한 결과는 흑마늘(36)에서 생마늘에 비하여 흑마늘의 총 페놀 함량이 높았고, 흑율피(4)에서 생율피보다 숙성 흑율피의 총 페놀 함량이 높고, 숙지황(35)에서 생지황보다 숙지황의 총 페놀 함량이 증가하는 보고와 같은 경향을 보였다. 이는 식물체 의 세포벽에 존재하던 bound형의 페놀 화합물이 장시간 열처리를 받아 free형의 페놀 화합물로 유리되어 용출되기 에 총 페놀 함량이 증가한다고 보고(37)한 결과와 같이, 고온의 항온과정에 의해 세포벽이 파괴되어 폴리페놀이 유리됨에 따라 총 페놀 함량이 증가한다고 생각된다. 이전 의 연구 결과(3)에서도 맥문동 성분 중 조사포닌 함량은 생맥문동이 $3.52 \%$, 열풍건조 맥문동은 $8.41 \%$ 이었고, spicadoside $\mathrm{A}$ 는 생맥문동에서는 $5.32 \mathrm{mg} \%$ 건조 맥문동에 서는 $18.21 \mathrm{mg} \%$ 로 가열처리 시 증가되었다.

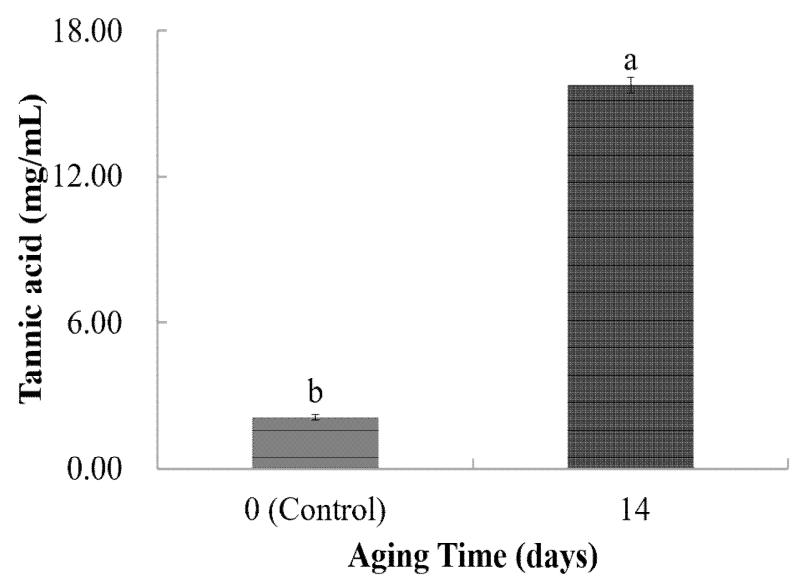

Fig. 1. Total phenol contents of Liriope platyphylla during storage. Control: Liriope platyphylla. Values represent the mean \pm SD ( $n=3)$. Means with different letters above a bar are significantly different at $\mathrm{p}<0.05$.

폴리페놀계 물질은 phenolic hydroxyl(-OH)기가 분자 내 2개 이상으로 구성된 방향족 화합물들을 말하며, 산화-환원 반응에서 기질로 작용하고 식물체에 특정한 색을 부여하기 도 하며 생체 내에서 다양한 생리활성을 나타내는 등의 다양한 기능을 가진다(4). 맥문동에 함유된 폴리페놀류에 는 사포닌, isoflavon과 homoisoflavonoid 계열 등이 있으며 이들이 항산화 활성에 관여한다고 보고되었다(38).

그리고 총 폴리페놀은 항산화효과와 유의한 상관관계가 있는 것으로 보고(39)된 물질이므로, 총 폴리페놀 함량이 더 높은 숙성 흑 맥문동의 항산화성이 대조군 맥문동보다 높다고 생각된다.

\section{DPPH radical 소거능}

$\mathrm{DPPH}$ 는 cysteine, glutathion과 같은 황 함유 아미노산이 
나 tocopherol, ascorbic acid, Maillard형 갈변생성물질 등의 항산화 물질에 의해 환원되어 탈색되는 정도로 항산화 활성 정도를 측정하는 데 쓰인다 $(4,40)$. 대조군 맥문동과 숙성 흑 맥문동의 항산화 활성을 평가하기 위해 DPPH radical 소거능을 측정하여 $\mathrm{DPPH}$ 의 free radical을 $50 \%$ 저해했을 때의 시료농도 $\left(\mathrm{IC}_{50}\right)$ 는 Fig. 2 와 같다. 대조군 맥문동의 $\mathrm{IC}_{50}$ 은 $114.43 \mathrm{mg} / \mathrm{mL}$, 숙성 14 일차 흑 맥문동의 $\mathrm{IC}_{50}$ 은 25.24 $\mathrm{mg} / \mathrm{mL}$ 로 더 낮았다. 즉, 숙성 흑 맥문동의 DPPH radical 소거능이 대조군 맥문동에 비해 약 4.5 배 높은 것으로 나타 났다. 이러한 결과는 숙지황(41)에서 생지황보다 숙지황이, 숙성 흑율피(4)에서 생율피보다 숙성율피의 DPPH radical 소거능 $\mathrm{IC}_{50}$ 값이 감소하며, 본 실험과 유사한 결과를 나타 내었다. 또한, 건조 맥문동이나 단순히 볶은 맥문동보다 찌거나 주증 처리한 후 볶았을 때 항산화 활성이 높았다는 보고와 일치하였다(20).

이 같은 결과는 맥문동의 주요 성분인 steroid saponin, homo-isoflavonoids, phytosterols 등의 성분들이 free radical 을 감소시킴으로써 항산화능을 높인 데 기인된 것이다 $(38,42,43)$. 또한, 맥문동 숙성과정 중 비효소적 갈변반응의 증대로 멜라노이딘 생성의 증가에 기인된 것으로 사료된다 (29). 총 폴리페놀은 항산화효과와 유의한 상관관계가 있는 것으로 보고(39)된 물질인데, 숙성 흑 맥문동의 총 폴리페놀 함량은 증가하였으므로(Fig. 1), DPPH radical 소거능이 대 조군 맥문동보다 높다고 생각된다.

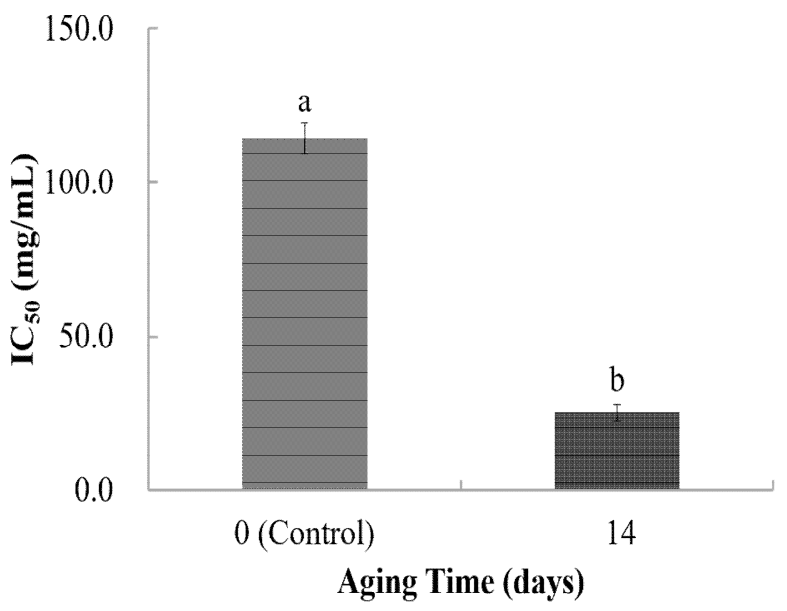

Fig. 2. DPPH radical scavenging activity of Liriope platyphylla during storage.

Control: Liriope platyphylla. Values represent the mean $\pm \mathrm{SD}(\mathrm{n}=3)$. Means with different letters above a bar are significantly different at $\mathrm{p}<0.05$.

\section{Hydroxyl radical 소거능}

대조군 맥문동과 숙성 흑 맥문동의 Hydroxyl radical 소거 능 $\mathrm{IC}_{50}$ 결과 값은 $\mathrm{Fig}$. 3과 같다. 대조군 맥문동의 $\mathrm{IC}_{50}$ 값은 $38.87 \mathrm{mg} / \mathrm{mL}$, 숙성 14 일차 흑 맥문동의 $\mathrm{IC}_{50}$ 값은 11.65 $\mathrm{mg} / \mathrm{mL}$ 로 더 낮고, 숙성 흑 맥문동의 Hydroxyl radical 소거
능이 대조군 맥문동에 비해 약 3.33 배 높은 것으로 나타났 다. 이러한 결과는 흑마늘(36)에서 흑마늘의 hydroxyl radical 소거능이 생마늘보다 더 높다고 한 보고와 유사한 경향을 나타냈다. 맥문동을 숙성하면 항산화능이 증진하는 데, 이는 총 페놀 함량이 숙성 맥문동에서 증가된 결과와 일치하였다. Hydroxyl $\operatorname{radical}(\cdot \mathrm{OH})$ 은 생체 내 산화적 손상 의 주요한 역할을 하는 활성산소종이다(44). Hydroxyl radical은 DNA의 핵산과 결합하여 산화적 손상을 유발하여 돌연변이 및 발암의 원인이 되며, 지질 산화의 개시제로 작용하므로 hydroxyl radical 소거활성은 지질과산화의 억 제 또는 활성산소종의 소거를 통한 연쇄반응을 저해하는 것으로 보고되었다(45).

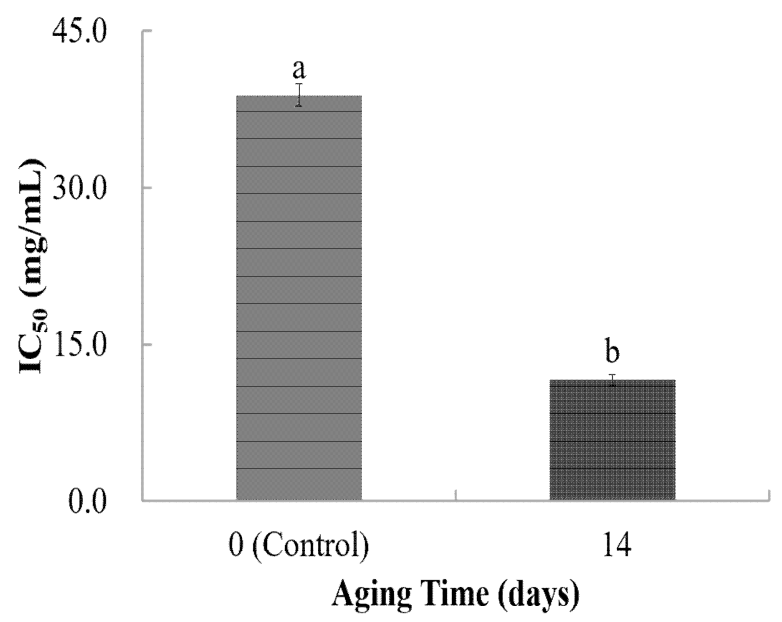

Fig. 3. Hydroxyl radical scavenging activity of Liriope platyphylla during storage.

Control: Liriope platyphylla. Values represent the mean $\pm \mathrm{SD}(\mathrm{n}=3)$. Means with different letters above a bar are significantly different at $\mathrm{p}<0.05$.

\section{요 약}

본 연구에서는 다양한 생리활성을 가지는 맥문동을 막걸 리에 침지 후 숙성시키면서 숙성기간에 따른 흑맥문동의 이화학적 특성 및 항산화성을 분석하였다. 수분함량은 숙 성기간이 경과됨에 따라 유의적으로 감소하였다. 가용성 고형물 함량 및 환원당은 숙성기간이 경과됨에 따라 유의적 으로 증가하였다. $\mathrm{pH}$ 는 숙성기간이 경과됨에 따라 유의적 으로 감소하였고, 산도는 유의적으로 증가하였다. 색도는 숙성이 진행될수록 $\mathrm{L}$ 값과 $\mathrm{b}$ 값은 유의적으로 감소하였던 반면, $\mathrm{a}$ 값은 유의적으로 증가하였다. 또한 갈변도는 맥문동 이 숙성될수록 유의적으로 증가하였다. 총 페놀 함량은 숙 성 흑 맥문동이 대조군 맥문동보다 값이 더 높았다. DPPH radical 소거능과 hydroxyl radical 소거능은 모두 숙성 흑 맥문동이 대조군 맥문동보다 $\mathrm{IC}_{50}$ 값이 더 낮아, 숙성 흑 맥문동의 항산화능이 높았는데, 이는 총 페놀 함량이 숙성 
이 진행되면서 증가한데 기인되었다. 본 연구 결과를 통해, 숙성과정을 거친 숙성 흑 맥문동은 가용성 고형물 함량, 환원당, 항산화성이 높게 나타났으므로 음료나 가공식품 개발 시 식품소재로서 폭넓게 활용될 수 있을 것으로 생각 된다.

\section{감사의 글}

본 연구는 충남대학교 학술연구비 지원에 의해 수행되었 으며, 이에 감사드립니다.

\section{References}

1. Cho HJ, Hyun BK, Sonn YK, Park CW, Chun HC, Song KC, Noh DC, Yun KH (2013) A study on soil suitability criteria for Liriopis platyphylla. J Soil Sci Fert, 46, 542-548

2. Kim JH, Kim JE, Lee YK, Nam SH, Her YK, Jee SW, Kim SG, Park DJ, Choi YW, Hwang DY (2010) The extracts from Liriope platyphylla significantly stimulated insulin secretion in the HIT-T15 pancreatic $\beta$-cell line. J Life Sci, 20, 1027-1033

3. Lee KS, Kim GH, Kim HH, Choi JW, Lee HC, Song MR, Kim MR, Lee GH (2009) Physiochemical characteristics of Liriope platyphylla tubers by drying process. J Korean Soc Food Sci Nutr, 38, 1104-1110

4. Kim JH, Lim WJ, Kim MR (2017) Quality Characteristics and antioxidant activities of aged black chestnut inner shells. J Korean Soc Food Sci Nutr, 46, 343-349

5. Jang JS (2018) Antioxidant activities of Liriope platyphylla L. extracts obtained from different solvents. Korean J Food Nutr, 31, 543-548

6. Park JC (2002) Handling, Functional food and natural product science. Hyoil Publishing Co., Seoul, Korea, p $52-53$

7. Korean council of biomedical professors, health functionality food textbook editing committee (2008) Handling, Functional foods and nutraceuticals. Dongmyeongsa Publishing Co., Paju, Korea, p 408-409

8. Shin JS (2002) Saponin composition of Liriope platyphylla and Ophiopogon japonicus. Korean J Crop Sci, 47, 236-239

9. Bae KM, Park SH, Jung KH, Kim MJ, Hong SH, Song YO, Lee HS (2010) Effects of roasting conditions on physicochemical properties and sensory properties of
Liriopos tuber. J Korean Soc Food Sci Nutr, 39, 1503-1508

10. Heo J (2001) Handling, Donguibogam. Hanmi Publishing Co., Seoul, Korea, p 1173

11. Kim SD, Ku YS, Lee IZ, Kim MK, and Park IK (2000) Major chemical components in fermented beverages of Liriopis tuber. J East Asian Soc Dietary Life, 10, 281-287

12. Im JG, Kang MS, Park IK, Kim SD (2005) Dietary effect of Liriopis tuber water extracts on the level of blood glucose and serum cholesterol in streptozotocin-induced diabetic rat. J East Asian Soc Dietary Life, 15, 20-28

13. Han Y, Jung HW, Lee DH, Kwon SY, Son KH, Park YK (2013) Anti-inflammatory effects of prosapogenin III from the dried roots of Liriope platyphylla in LPS-stimulated RAW264.7 cells. J Asian Nat Prod Res, $15,1038-1049$

14. Baek SI, Jo SJ, Bang MH, Lee IJ, Park CG, Kim MS, Kim GS, Sung JD (1998) Anti-cancer activity of Liriope platyphylla W. T. steroid saponin. J Appl Biol Chem, 41, 390-394

15. Jo YM, Hong YC (2014) Research institue for healthcare policy korean medical association. Med Policy Forum, $12,32-36$

16. Jang AS (2015) Particulate matter and bronchial asthma. Korean J Med, 88, 150-155

17. Jung HJ, Jung GJ, Jung SK, Lee HK (2005) Liripois tuber contributes to the chemotaxis of eosinophils and secretion of cytokines in A549 human epithelial cells. J of Oriental Chr Dis, 10, 1-20

18. Jung HJ, Jung HJ, Jung SK, Lee HK (2002) The inhibitory effects of Maekmundongcheongpye-eum and Liriopis tuber on the IL-6, IL-16 and GM-CSF mRNA levels in human epithelial cells. J Korean Orient Med, 23, 11-23

19. KFDA (2014) Food Code. Food and Drug Administration, Food Code. Seoul, Korea, p 318

20. Yang MO (2013) Antioxidant and sensory properties of hot water extract of Liriope tubers treated at various preprocess. J East Asian Soc Diet Life, 23, 645-653

21. Park JH, Jin SY (2018) Antioxidant activity and quality characteristic of Sulgidduk added Liriope platyphlla powder. Korean J Food Cook Sci, 34, 49-56

22. Park SH, Ryu HK (2013) The quality characteristics of noodles containing roasted Liriopis tuber. J Korean Soc Food Sci Nutr, 42, 1096-1102

23. Park C, Park SH, Kim WB, Hwang JH, Lee H (2017) Quality characteristics and reduced sugar conditions of Yanggaeng prepared with steamed Liriopis tuber extract 
using response surface methodology. J Korean Soc Food Sci Nutr, 46, 229-236

24. Lee YJ, Kim YH, Lee KA (2018) Antioxidative and antidiabetic effects and free amino acid analysis of drinks with Gugija (Lycii fructus) and Maegmundong(Liriope platyphylla) extract powders. Korean J Food Cook Sci, 34, 178-185

25. Song JH, Baek SY, Lee DH, Jung JH, Kim HK, Lee JS (2011) Screening of fungal Nuruk and yeast for brewing of Gugija-Liriope tuber traditional rice wine and optimal fermentation condition. Kor J Mycol, 39, 78-84

26. Ming JH, Nam YG, Ju JI, Jung JH, Lee JS, Kim HK (2012) Changes in yeast and bacterial flora during fermentation and storage of Gugija-Liriope tuber makgeolli using PCR-DGGE. Korean J Microbiol Biotechnol, 40, 111-116

27. Kim MR (2017) Anti-oxidant aged chestnut inner shell and anti-oxidant composition comprising the aged chentnut Inner shell or its extract. KOREA Patent No. 1020170022929

28. AOAC (1990) Official Methods of Analysis. $15^{\text {th }}$ ed, Association of Official Analytical Chemists, Washington DC, USA, p 777-784

29. Singleton VL, Rossi JA (1965) Colorimetry of total phenolics with phosphomolybdic-phosphotungstic acid reagents. Am J Enol Vitic, 16, 144-158

30. Choi DJ, Lee SJ, Kang MJ, Cho HS, Sung NJ, Shin JH (2008) Physicochemical characteristics of black garlic (Allium sativum L.). J Korean Soc Food Sci Nutr, 37, 465-471

31. Kim HJ, Lee JY, You BR, Kim HR, Choi JE, Nam KY, Moon BD, Kim MR (2011) Antioxidant activities of ethanol extracts from black ginseng prepared by steaming-drying cycles. J Korean Soc Food Sci Nutr, 40, $156-162$

32. Lee MH, Kim KT, Lee KH (2012) Quality characteristics of ginger (Zingiber officinale roscoe) as the ripening periods. J Fd Hyg Safaty, 27, 479-486

33. Kim YR, Ha JH, Kim SR, Park YC, Kim KC, Kim WI, Ryu SH, Kim HY (2016) Investigation of microbial contamination in Liriope platyphylla at post harvest environments. J Food Hyg Saf, 31, 99-106

34. Oh HL, Kim CR, Kim NY, Jeon HL, Doh ES, Kim MR (2013) Characteristics and antioxidant activities of Rehmanniae radix powder. J Korean Soc Food Sci Nutr, 42, 62-67
35. Lee TJ, Hwang DY, Lee CY, Son HJ (2009) Changes in organic acid in the production and distribution of makgeolli. Kor J Microbiol, 45, 391-396

36. You BR, Kim HR, Kim MJ, Kim MR (2011) Comparison of the quality characteristics and antioxidant activities of the commercial black garlic and lab-prepared fermented and aged black garlic. J Korean Soc Food Sci Nutr, 40, 366-371

37. Kang KM, Lee SH (2013) Effects of extraction methods on the antioxidative activity of Artemisia sp.. J Korean Soc Food Sci Nutr, 42, 1249-1254

38. Kim SD, Ku YS, Lee IZ, Park IK, Youn KS (2001) Optimization for hot water extraction condition of Liriope spicata tuber using response surface methodology. Korean J Postharvest Sci Technol, 8, 157-163

39. Kwak CS, Kim SA, Lee MS (2005) The correlation of antioxidative effects of 5 korean common edible seaweeds and total polyphenol content. J Korean Soc Food Sci Nutr, 34, 1143-1150

40. Choi IY, Song YJ, Lee WH (2010) DPPH radical scavenging effect and antimicrobial activities of some herbal extracts. Kor J Hort Sci Technol, 28, 871-876

41. Kim HJ, Lee JY, You BR, Doh ES, Kim MR (2011) Antioxidant activities of Rehmannia glutinosa by traditional methods. Korean J Medicinal Crop Sci, 19, 341-346

42. Kang MJ, Kim DW, Kang JR, Shin JH (2018) Effect of roasting time on physicochemical characteristics and antioxidant activity of hot water extracts of dried Liriope platyphylla. Korean J Food Preserv, 25, 246-254

43. Oh SH, Chung JH, Kim YH, Cho JH (2006) Study on antioxidative effects of polyphenols extracted from chestnut inner shell. Spring meeting of Korean Society of Medicinal Crop Science, Cheonan, Korea, p 536-537

44. Kim JW, Minamikawa TK (1997) Hydroxy radical scavenging effects of spices and scavengers from brown mustard (Brassica nigra). Biosci Biotechnol Biochem, 61, 118-123

45. Manian R, Anusuya N, Siddhuraju P, Manian S (2008) The antioxidant activity and free radical scavenging potential of two different solvent extracts of Camellia sinensis (L.) O. Kuntz, Ficus bengalensis L. and Ficus racemosa L.. Food Chem, 107, 1000-1007 